\title{
THE SOIL TEMPERATURE REGIME IN THE URBAN AND SUBURBAN LANDSCAPES OF OLOMOUC, CZECH REPUBLIC
}

\author{
Michal LEHNERT
}

\begin{abstract}
The soil temperature regime is a relevant part of comprehensive topoclimatic research. Soil temperature data series measured at selected stations of the metropolitan station system of Olomouc in 2010-2011 were analysed. The focus was on the identification of geofactors influencing the soil temperature regime in the area of interest. The possibility of soil temperature simulation using knowledge of local specifics of the soil temperature regime was verified. The results indicate that the variability of the soil temperature regime was, apart from physical and chemical properties of soil, determined predominately by the character of the relief and the occurrence of related atmospheric inversions. The impact of the urban landscape on the soil temperature regime was not demonstrated. Average daily soil temperature was simulated with satisfying results, based on a model adjusted for a period without snow cover. The results represent a basis for further research on geofactors influencing the soil temperature regime in Olomouc and its surroundings.
\end{abstract}

\section{Shrnutí}

\section{Režim teploty pưdy v městské a příměstské krajině Olomouce, Česká republika}

Režim teploty pưdy je dưležitá součást komplexního topoklimatického výzkumu. Na základě dat $z$ účelové staniční sítě byla analyzována teplota půdy v letech 2010-2011. Cílem bylo identifikovat hlavní geofaktory ovlivňující režim teploty půdy v zájmovém území. Ověřována byla také možnost využití znalostí místních specifik režimu teploty půdy pro simulaci puidní teploty. Ukázalo se, že variabilita teploty půdy byla kromě fyzikálně-chemických vlastností pưdy podmíněna zejména charakterem reliéfu a souvisejícím výskytem inverzí. Samotný vliv města na teplotu půdy se prokázat nepodařilo. Na základě upraveného modelu byla s dobrou presností simulována průměrná denní teplota půdy v teplém půlroce. Získané poznatky predstavují základ pro studium vlivu jednotlivých geofaktorů na režim teploty pưdy $v$ Olomouci a okolí.

Keywords: soil temperature regime, soil temperature simulation, Olomouc and its surroundings, Czech Republic

\section{Introduction}

Thermal and temperature soil characteristics are part of fundamental physical properties in soil science. Since the first modern research conducted by De Vries (1952), a number of publications thoroughly describing heat transfer in soils have been published. Nevertheless, the current state of knowledge is only used with difficulties from the climatological point of view, as geographical space varies significantly (soil properties, topography, weather conditions, etc.). Consequently, the spatial and temporal distribution of soil temperature and predictions of soil temperatures are considerably underdeveloped in comparison with other fields of study in climatology. Some local climatic effects may, however, be affected by the soil temperature regime (Vysoudil, 2009). For instance, the soil temperature regime might affect air temperature and relative air humidity regimes near the ground. This could lead to local radiation inversions.

Permanent long-term soil temperature measurements in the Czech Republic are made mainly by a professional meteorological station. Data analyses and assessments are usually limited to descriptions of the soil temperature regime on a macroclimatic level (Bedrna, Gašparovič, 1980; Coufal et al., 1993; Tolasz et al., 2007). As a result, detailed analyses on a local climate level, which would include a dense grid of sites, are made only rarely (Pokladníková et al., 2006; Tesař et al., 2008; Lehnert, 2010; Hora, 2011). 
The approach taken in this study is based on the description of particular geofactors and their influence on the soil temperature regime. According to Hanks (1992), geofactors shaping the soil temperature regime can be distinguished:

1. as those influencing the amount of heat available on the soil surface; and

2. those influencing the dissipation of available heat.

Research on factors influencing dissipation of available heat has strong roots in soil science and therefore there are many reports describing the influence of particle size, soil moisture content, humus (or organic matter) content and porosity, on heat flows in the soils (see Hanks, 1992; Geiger et al., 2003; Horton, Hochster, 2011). On the other hand, a systematic description of the factors the amount of heat available on the soil surface is clearly missing. Nevertheless, geofactors influencing the amount of heat available on the soil surface can be considered to include relief (Elizbarashvili, 2007; Kim et al., 2000), vegetation (Green et al., 1984), soil cover colour (Oke, Hannell, 1966), the complex relation of air temperature and air humidity in terms of water vapour condensation in soil pores (Hofmann, 1955), climatic conditions in general (Elizbarasvilli, 2007), and/or the influence of the urban environment (Tang et al., 2011).

Since recognition of the influences of all geofactors is a demanding task at a level to meet acceptable accuracy in the space-time continuum, most relevant studies were published during the last two decades when computerized spatial statistics tools became available. The results of Balland and Arp (2005), who managed to generalize the influence of geofactors on soil thermal conductivity over a wide range of conditions, encouraged the development of soil temperature regime models applicable in various geographic conditions. Meanwhile, Kang et al. (2000) presented a hybrid soil temperature regime model based on the influence of topography, active surface characteristics and air temperature on soil temperature, which has excellent accuracy for the investigated area.

Despite the fact that the above-mentioned models have brought the most satisfactory results, they cannot be considered comprehensive or widely applicable to various geographic situations at this time. For instance, almost none of the existing models take into account the variety of local climate dynamics. Knowledge of the influence of the spatial variations in climatic factors on the soil temperature regime is very poor.

This situation emphasizes the level of uncertainty in soil temperature regime simulations. Furthermore, Kutílek (1990) demonstrated a free correlation of "hydrotope" and "pedotope", which (to some extent) presents a limitation on the soil temperature regime simulation on a local scale.

The particular aim of this study is to identify the geofactors determining the soil temperature regime in Olomouc and in its surrounding areas. At the same time, the paper aims to create a basis for a simple but comprehensive approach to soil temperature regime simulation in the area under investigation. Therefore, the paper presents both a description of the soil temperature regime, analysing the influence of the geofactors, and an experimental attempt to demonstrate the applicability of knowledge of the spatial variability of local soil temperature, for soil temperature simulation in the investigated area.

\section{Data and methods}

The soil temperature analysis was primarily based on data obtained from the six stations included in the metropolitan station network of Olomouc (MESSO), see Tab. 1. The analyzed soil temperatures were measured at a depth of $0.2 \mathrm{~m}$ in 2010 and 2011 . The specified stations measured, among other variables, air temperature at a height of $1.5 \mathrm{~m}$ and precipitation intensity. Moreover, the BYST, DDHL and ENVE stations measured global radiation. The global radiation data measured at the ENVE station was used for the nearby BOT_PF, DOMI and LETO stations. There were no soil temperatures measured at ENVE; therefore the station is grey-tinged in Table 1. More detailed information about the MESSO stations was presented by Vysoudil et al. (2012).

The data were recorded at 10-minute intervals and processed according to the procedures of Nosek (1972). Daily, monthly and annual maximum and minimum soil temperatures were determined. Average soil temperatures were calculated as an arithmetic mean of all corresponding values measured at 10-minute intervals. Air temperature data, which were used for comparative analyses and for the soil temperature simulation, were treated similarly. For selected days, hourly sums of precipitation and hourly averages of global radiation were also calculated. Snow cover depth was measured at the Olomouc-Holice station of the Czech Hydrometeorological Institute (for more details see Vysoudil et al., 2012).

Besides the previously-mentioned analyses of meteorological characteristics, some soil properties were also specified. More precisely, soil texture (due to technical reasons, the smallest measured grain that includes fine silt and clay was limited to $\leq 0.063 \mathrm{~mm}$ ) and soil humus content were determined. Soil samples 


\begin{tabular}{|l|c|c|c|c|c|c|}
\hline \multicolumn{1}{|c|}{ Site } & Location $(\phi)$ & Location $(\lambda)$ & Altitude (m a.s.l.) & Site position & Topography & Soil type \\
\hline BOT_PF & $49^{\circ} 36^{\prime} 01^{\prime \prime}$ & $-17^{\circ} 15^{\prime} 27^{\prime \prime}$ & 211 & urban & flat land & Urbic Anthrosol \\
\hline BYST & $49^{\circ} 32^{\prime} 33^{\prime \prime}$ & $-17^{\circ} 11^{\prime} 16^{\prime \prime}$ & 218 & rural & flat land & Luvic Chernozem \\
\hline DDHL & $49^{\circ} 39^{\prime} 36^{\prime \prime}$ & $-17^{\circ} 24^{\prime} 33^{\prime \prime}$ & 307 & rural & valley & Haplic Gleysol \\
\hline DOMI & $49^{\circ} 35^{\prime} 49^{\prime \prime}$ & $-17^{\circ} 15^{\prime} 03^{\prime \prime}$ & 220 & urban & flat land & Urbic Anthrosol \\
\hline KOPE & $49^{\circ} 37^{\prime} 39^{\prime \prime}$ & $-17^{\circ} 20^{\prime} 20^{\prime \prime}$ & 362 & suburban & slope & Stagnic Luvisol \\
\hline LETO & $49^{\circ} 35^{\prime} 29^{\prime \prime}$ & $-17^{\circ} 12^{\prime} 35^{\prime \prime}$ & 258 & suburban & flat land & Urbic Anthrosol \\
\hline ENVE & $49^{\circ} 35^{\prime} 30^{\prime \prime}$ & $-17^{\circ} 15^{\prime} 46^{\prime \prime}$ & 230 & urban & (roof) & - \\
\hline
\end{tabular}

Tab. 1: Characteristics of the MESSO stations included in the study

were taken repeatedly from a soil borehole on 13 October 2011 in line with the methodology published by Zbíral, Honsa and Malý (1997).

In the following stage of this study, a simple empirical model published by Zheng et al. (1993) was used. The model is based on a daily average soil temperature simulation using air temperature data. The elemental version of this model was adopted as a tool for the experimental quantification of local differences in soil temperature simulation. The Zheng et al. (1993) model was chosen because of its accuracy, simplicity and flexibility, validated by Kang et al. (2000).

The above-quoted model is based on the so-called 'regional' regression equation (Zheng et al., 1993). The regional regression equation uses the correlation between the average daily soil temperature and the 11day moving average of air temperature. Consequently, data obtained from the regional equation calculations were incorporated into one of the empiricallydeveloped formulas. In this study, we used a simple version of the model, which is applicable only to the period without snow cover:

$$
F(J)=[A(J)-A(J-1)] M_{2}+E(J-1)
$$

in which $F(J)$ is the simulated average soil temperature for day $J ; A(J)$ is the measured average air temperature for day $J ; A(J-1)$ is the measured average soil temperature on the day preceding the day $J ; M_{2}$ is an empirically given constant 0.2 , and $E(J-1)$ is the soil temperature on the previous day estimated solely from the regional regression equation. The author's intention was to experimentally express spatial variations of soil temperature on a local level. Therefore, a LGF variable (Local Geographical Factors) was added to the formula (see below). LGF is assumed to quantify the specific influence of geofactors on the soil temperature of the monitored stations.

It is important to mention some differences in the initial data series of this study and the research carried out by Zheng et al. (1993). In our research, the soil temperature was measured at a depth of $20 \mathrm{~cm}$, whereas Zheng et al. (1993) measured at a depth of $10 \mathrm{~cm}$. We chose the depth of $20 \mathrm{~cm}$ because it is widely used in meteorological stations. Since the influence of snow cover could have concealed some required information, the calculations of soil temperature simulation in this paper are based only on the data series obtained during the period from May to October.

\section{Soil temperature regime}

There were significant differences between the annual soil temperature regimes in 2010 and 2011 (Figs. 1 and 2, Tabs. 2 and 3). Regardless of these differences,

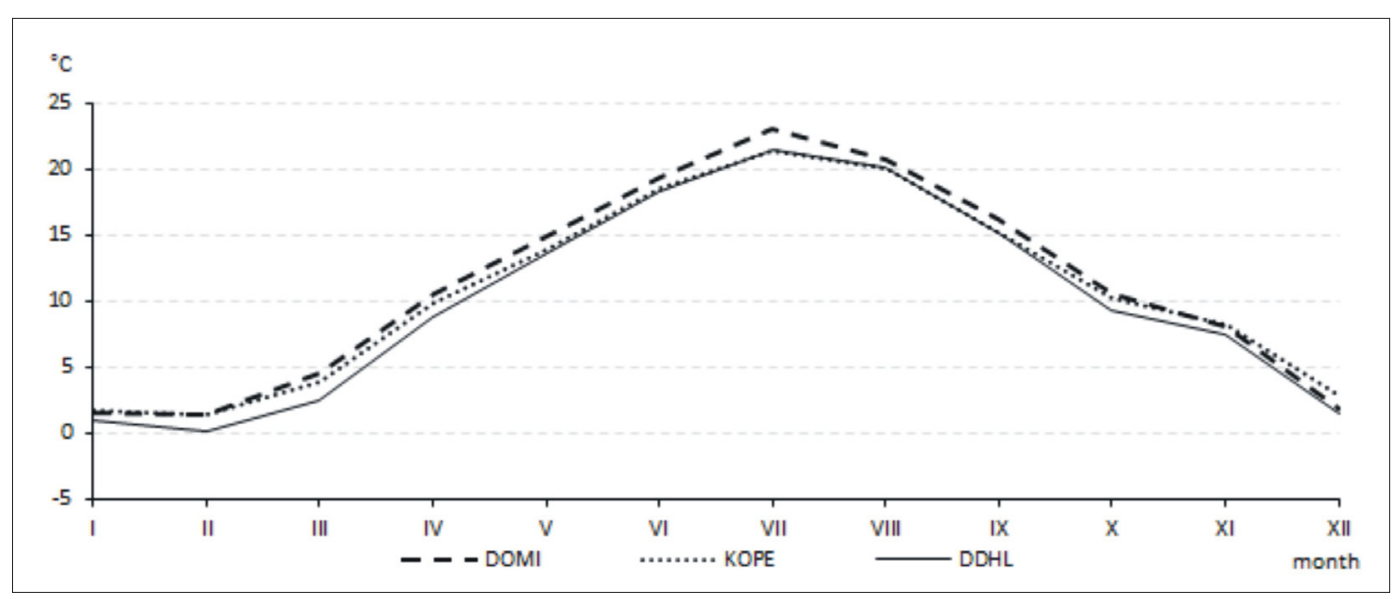

Fig. 1: Average soil temperatures at selected MESSO stations, 2010 


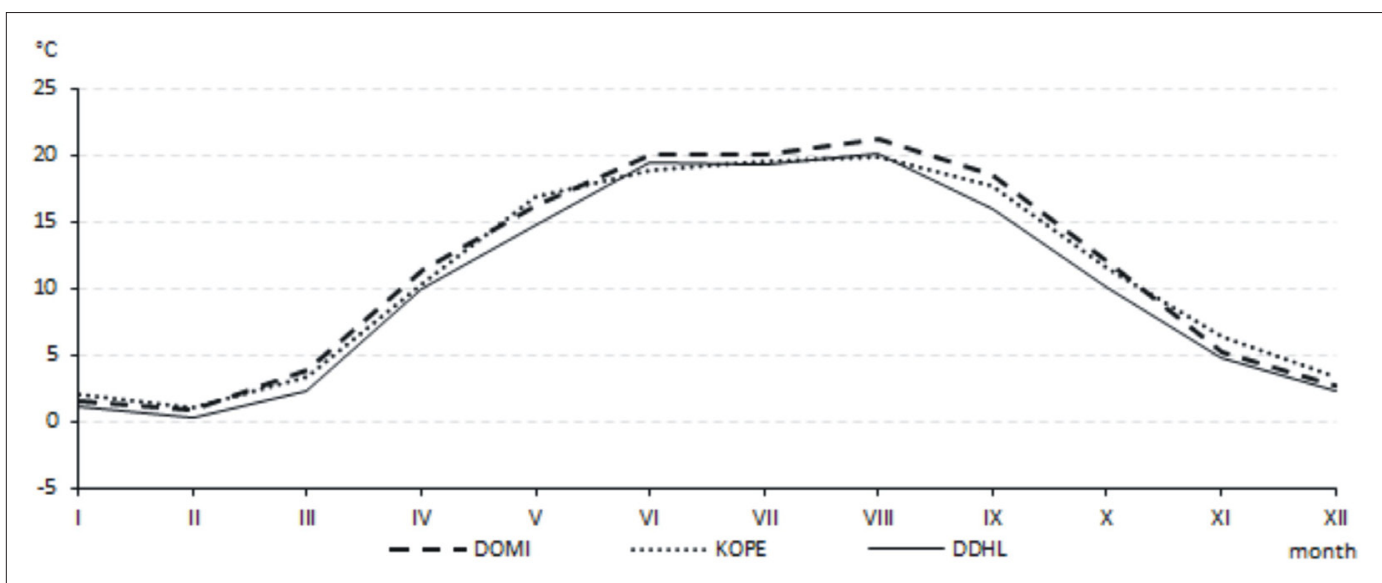

Fig. 2: Average soil temperatures at selected MESSO stations, 2011

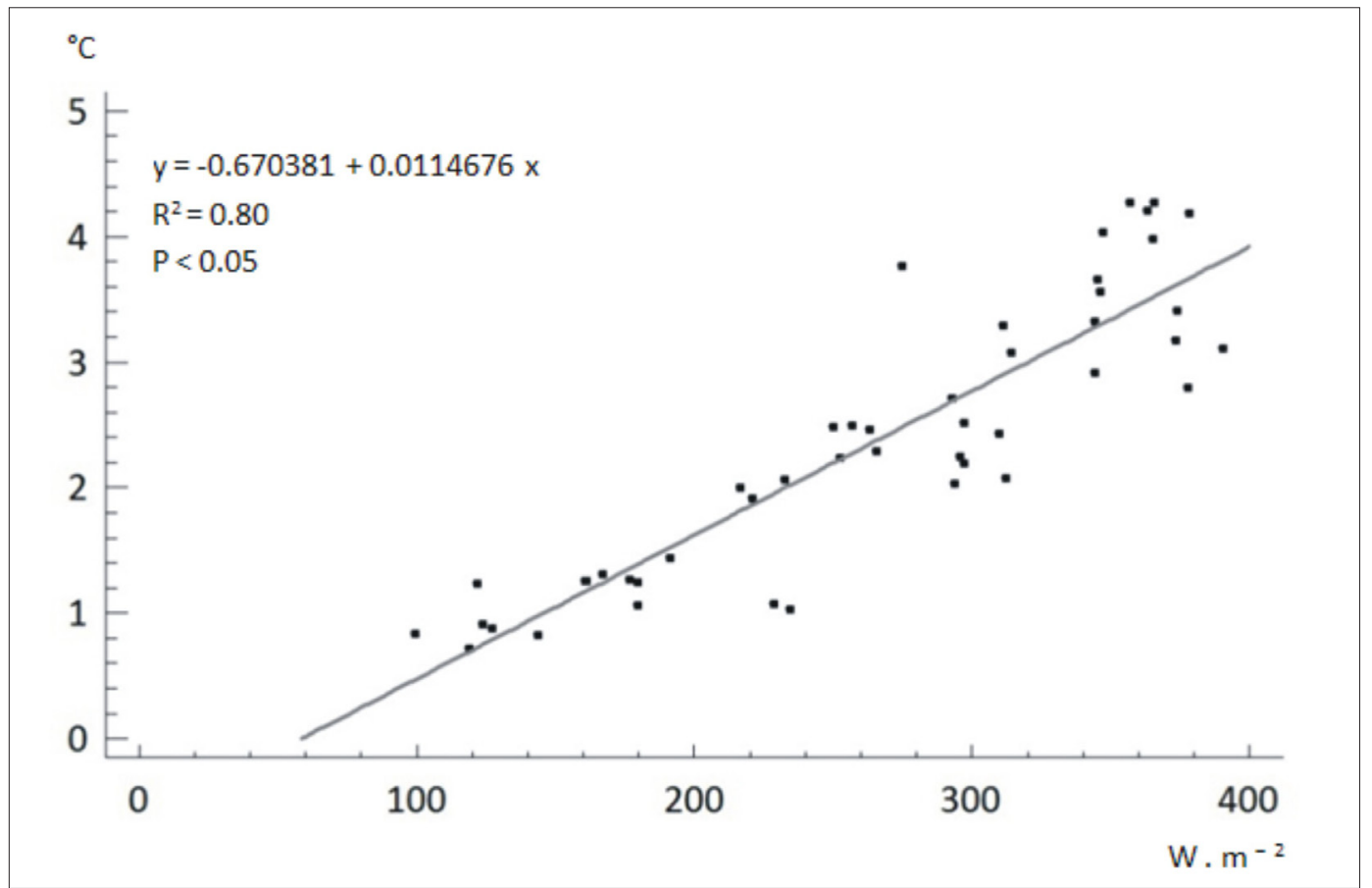

Fig. 3: Daily soil temperature amplitude and average daily global radiation intensity, MESSO 2010-2011

\begin{tabular}{|c|c|c|c|c|c|c|c|c|c|c|c|c|c|c|}
\hline Station & Year & I & II & III & IV & V & VI & VII & VIII & IX & $\mathbf{x}$ & XI & XII & Avg \\
\hline \multirow{2}{*}{ BOT_PF } & 2010 & 1.4 & 1.3 & 4.4 & 10.0 & 14.2 & 18.7 & 21.9 & 19.8 & 15.2 & 9.7 & 8.0 & 1.8 & 10.5 \\
\hline & 2011 & 1.5 & 1.0 & 3.9 & 10.0 & 14.3 & 19.0 & 18.8 & 19.7 & 16.6 & 10.8 & 5.0 & 2.8 & 10.3 \\
\hline \multirow{2}{*}{ BYST } & 2010 & 1.2 & 0.7 & 3.7 & 9.7 & 14.3 & 18.7 & 21.8 & 20.4 & 15.8 & 10.5 & 8.4 & 2.1 & 10.6 \\
\hline & 2011 & 0.9 & 0.9 & 3.7 & 10.5 & 15.2 & 18.6 & 17.7 & 18.5 & 16.6 & 11.3 & 5.7 & 3.2 & 10.2 \\
\hline \multirow{2}{*}{ DOMI } & 2010 & 1.6 & 1.4 & 4.5 & 10.5 & 14.8 & 19.4 & 23.1 & 20.7 & 16.2 & 10.5 & 8.0 & 1.9 & 11.0 \\
\hline & 2011 & 1.5 & 0.9 & 3.9 & 11.4 & 16.2 & 20.1 & 20.0 & 21.2 & 18.6 & 12.0 & 5.2 & 2.7 & 11.1 \\
\hline \multirow{2}{*}{ DDHL } & 2010 & 0.9 & 0.1 & 2.5 & 8.8 & 13.7 & 18.3 & 21.4 & 20.1 & 15.1 & 9.3 & 7.4 & 1.4 & 9.9 \\
\hline & 2011 & 1.1 & 0.3 & 2.3 & 10.0 & 14.8 & 19.4 & 19.3 & 20.2 & 16.0 & 10.2 & 4.7 & 2.2 & 10.0 \\
\hline \multirow{2}{*}{ KOPE } & 2010 & 1.7 & 1.3 & 3.9 & 9.8 & 13.9 & 18.6 & 21.4 & 20.1 & 15.1 & 10.2 & 8.3 & 2.8 & 10.6 \\
\hline & 2011 & 2.0 & 1.0 & 3.4 & 10.3 & 16.8 & 18.9 & 19.5 & 19.9 & 17.7 & 11.6 & 6.3 & 3.4 & 10.9 \\
\hline \multirow{2}{*}{ LETO } & 2010 & 1.1 & 0.7 & 3.8 & 9.5 & 13.5 & 17.2 & 21.9 & 20.3 & 15.3 & 10.0 & 8.0 & 5.4 & 10.6 \\
\hline & 2011 & 0.6 & 0.6 & 3.4 & 10.3 & 15.4 & 19.6 & 19.6 & 20.3 & 17.9 & 11.6 & 1.2 & 2.8 & 10.3 \\
\hline
\end{tabular}

Tab. 2: Average soil temperatures at selected MESSO stations, 2010-2011 


\begin{tabular}{|l|c|c|c|c|}
\hline \multirow{2}{*}{ Station } & \multicolumn{2}{|c|}{$\begin{array}{c}\text { Maximum } \\
\text { temperature }\end{array}$} & \multicolumn{2}{c|}{$\begin{array}{c}\text { Minimum } \\
\text { temperature }\end{array}$} \\
\cline { 2 - 5 } & {$\left[{ }^{\circ} \mathrm{C}\right]$} & Date & {$\left[{ }^{\circ} \mathrm{C}\right]$} & Date \\
\hline BOT_PF & 23.3 & 17.7 .2010 & 0.1 & 26.2 .2011 \\
\hline BYST & 22.2 & 18.7 .2010 & 0.4 & 28.2 .2011 \\
\hline DDHL & 23.9 & 26.8 .2011 & -0.7 & 26.2 .2011 \\
\hline DOMI & 24.8 & 26.8 .2011 & 0.1 & 27.2 .2011 \\
\hline KOPE & 23.3 & 26.8 .2011 & 0.3 & 4.3 .2011 \\
\hline LETO & 23.0 & 25.8 .2011 & -0.1 & 26.2 .2011 \\
\hline
\end{tabular}

Tab. 3: Maximum, minimum soil temperature at the selected MESSO stations, 2010-2011

neither 2010 nor 2011 were considerably warmer or colder than each other. In 2010, maximum soil temperatures were recorded by most MESSO stations at the end of July while maximum soil temperatures in 2011 were recorded at the end of August. Mean annual soil temperatures recorded at the BOT_PF, BYST and LETO stations were higher in 2010 , in contrast to temperatures measured at the DOMI, DDHL and KOPE stations. The highest average soil temperature was measured at DOMI station both in 2010 and 2011. Another significant feature was a later soil temperature increase measured at the DDHL station in the spring of both years.

Apart from the average, minimum and maximum daily and annual temperatures, the daily soil temperature amplitude was observed. The daily soil temperature amplitude increased principally with global radiation intensity in the course of the year. The correlation of global radiation intensity and average soil temperature is illustrated on the radiation weather days in Fig. 3. On days when the weather conditions failed to meet the definition of radiation weather days (wind velocity $\leq 4 \mathrm{~m} \cdot \mathrm{s}^{-1}$, proportion of sky covered by clouds $\leq 2 / 8$ ), weather influencing factors were taken into consideration.

\section{Factors influencing the soil temperature regime}

It follows from the above that global radiation is a determining geofactor influencing the soil temperature regime. However, a detailed analysis of Figures 4 and 5 reveals some other notable relations. It should be noted that the maximum and minimum daily soil

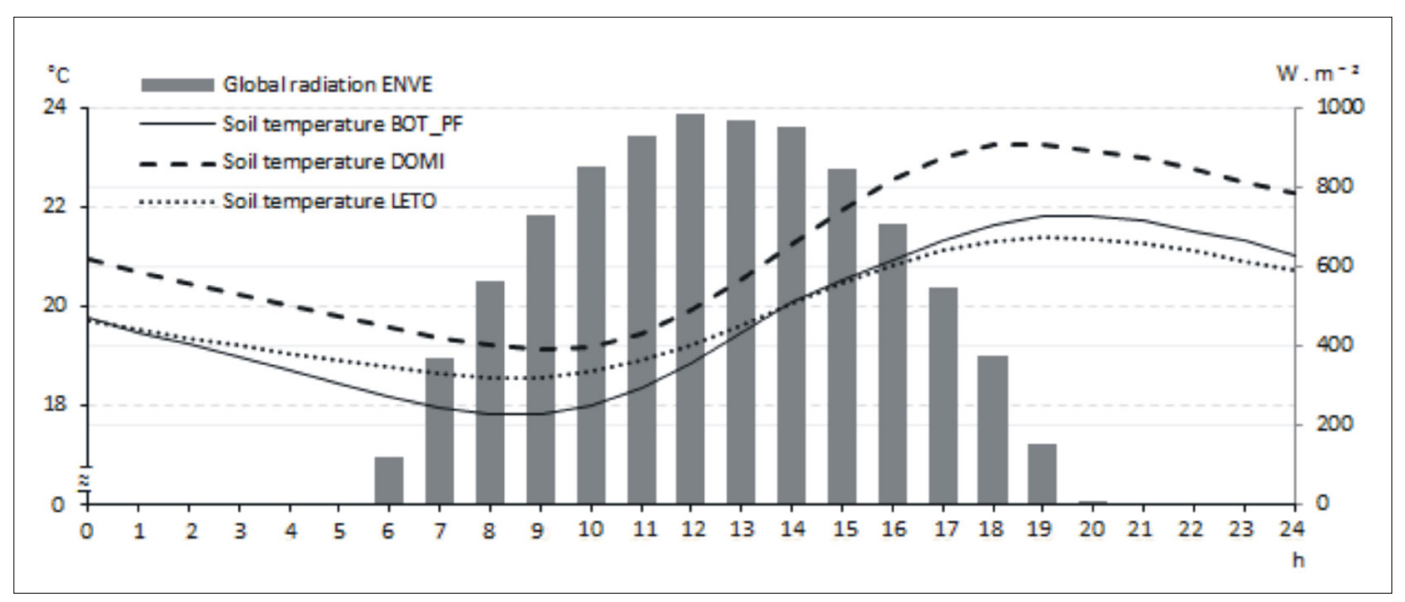

Fig. 4: Soil temperature and global radiation on the selected MESSO stations, 8 July, 2010

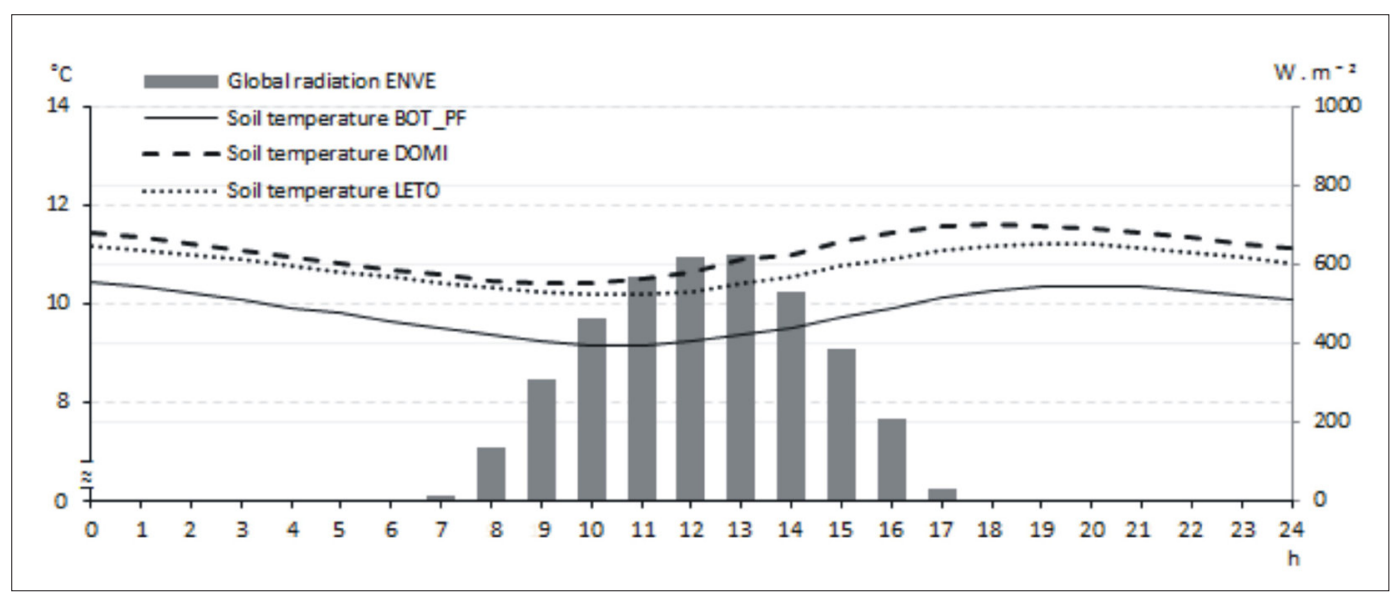

Fig. 5: Soil temperature and global radiation on the selected MESSO stations, 12 October, 2010 
temperatures were recorded at each station on different dates and that there were significant differences in the daily soil temperature amplitude between the involved stations. The reasons depended on the interaction of global radiation heat with other geofactors.

With respect to the fact that global radiation plays a key role in the formation of the soil temperature regime, it is crucial to deal with the influence of factors that might reduce global radiation intensity on a local scale. In Olomouc and the surrounding areas, the spatial variability of global radiation was influenced particularly by low cloudiness related to atmospheric temperature inversion. For instance, the soil temperature regime had an entirely different character at the highest altitude for the KOPE station compared with all other MESSO stations during the third ten-day interval in December 2010 (Fig. 6). The occurrence of air temperature inversion was corroborated by air temperature analyses. Another example of the impact of air temperature inversion on the soil temperature regime is the local climate of the V-shaped Bystřice River valley, where the DDHL station is located. Vysoudil (2008) confirmed that atmospheric temperature inversions reduced the intensity of global radiation on the Bystrice River valley bottom, and it was reconfirmed by an unpublished global radiation analysis by the author for the years 2010 and 2011. Therefore, the soil temperature regime at the DDHL station was characterised by a sudden soil temperature decrease at the end of the summer period and by a delayed soil temperature increase at the end of the winter period. Nonetheless, it should be noted that the soil temperature regime of DDHL was also conditioned by the valley shape.

Undoubtedly, the low cloudiness associated with air temperature inversion was not the only category of cloudiness shaping the local differences in global radiation intensity. Nevertheless, the local differences in cloudiness based on frontal circulation must be subject to further investigation. On days with the predominating influence of frontal circulation, the times of maximum and minimum temperature occurrence were shifting by minutes or even hours (Lehnert, 2010).

When cloudiness induced precipitation, the soil temperature suddenly decreased (Fig. 7). The phenomenon could have been caused by two different mechanisms - by water convection or by evaporation. The first one assumes decreased soil temperature due to infiltration of colder water into the soil. The second one counts on increased loss of latent heat from the soil due to increased evaporation.

Relief was another significant geofactor affecting the soil temperature regime. The influence of slope aspect was not taken into account because the data used were measured at the meteorological stations. Despite this, it is unrealistic to avoid the effect of shading of the meteorological stations by the surrounding relief, which significantly affected the soil temperature regime at the DDHL station in particular. For example, during the sunrise on 30 October 2010, nonzero values of global radiation were detected on the DDHL station with an hour lag at the ENVE station (Lehnert, 2012). Consequently, shorter daily durations of global radiation at the DDHL station were detected. These changes had an impact on the minimum daily soil temperature data and also on the average soil temperature value at the DDHL station. On the other hand, according to Lehnert (2012), the effect of altitude was not substantial in the study area.

Global radiation is partly transformed into heat energy on the ground. The efficiency of this process is given by properties of the active surface. In spite of the fact that the active surface at all of the studied

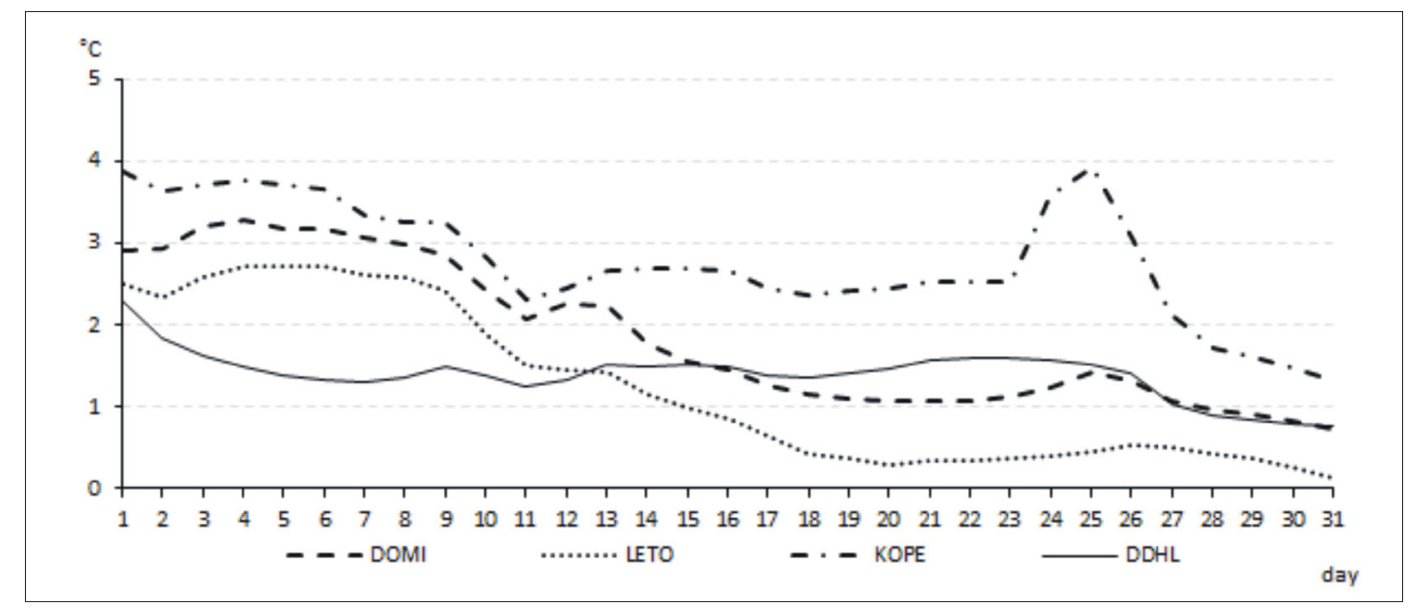

Fig. 6: Average soil temperature, Olomouc and surroundings, December 2010 
MESSO stations was maintained lawn, properties of this active surface for all stations were not identical. It was discovered that even seemingly insignificant differences in grass quality (sward height and density) might have an influence on soil temperature (see Lehnert, 2012).

With respect to land cover type, the presence of snow had a major influence on the soil temperature regime. With snow cover present, there was almost no response of soil temperature to global radiation intensity; the course of soil temperature during these days was flat. Therefore, the spatial and temporal variations in snow cover have an impact on the spatial variation of the soil temperature regime (for more details, see Lehnert, 2012). Even a snow cover of less than $5 \mathrm{~cm}$ might have changed the soil temperature regime dramatically. Another effect of snow cover becomes important upon the start of snow melting. For instance, soil temperature remained steady or decreased almost imperceptibly at first, and then rose sharply during the thaw at the end of January 2010, which could be due to a sudden and intense emission of latent heat from the saturated soil.
As mentioned above, soil properties represent an important group of geofactors affecting the soil temperature regime. Therefore, we analyzed relations between the average daily soil temperature amplitude and the humus content, and between the average daily soil temperature amplitude and the size of particles. While the role of humus content was ambiguous, there seemed to be a positive correlation between the average daily soil temperature amplitude and the proportion of sand fraction in fine earth (though without statistical significance due to few input data points). This implies that coarse soils have higher average daily soil temperature amplitude than fine soils (Fig. 8). The effect of soil type by itself was particularly obvious in gleysol at the DDHL station, where both the second highest absolute temperature and the lowest annual temperature were detected.

\section{Geofactors as a variable in soil temperature regime calculation}

In the first part of this research project with the preliminary results described above, some important geofactors influencing the soil temperature regime are

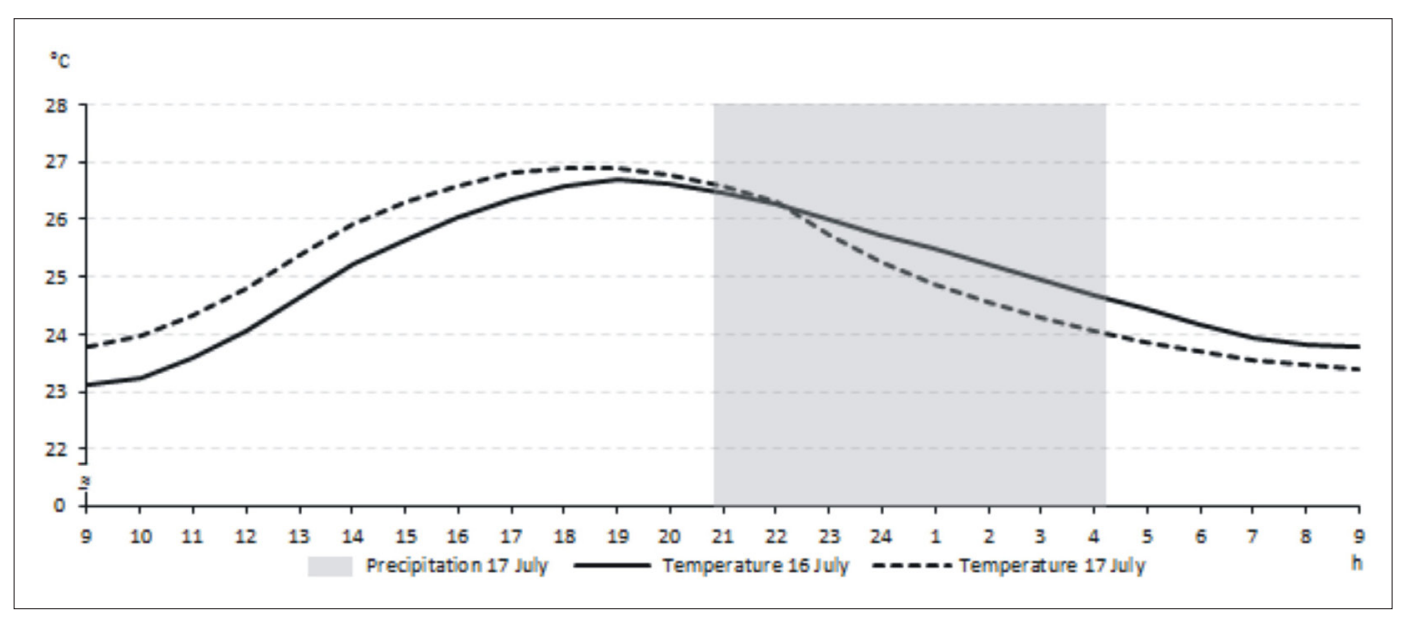

Fig. 7: Diurnal soil temperature regime and distribution of precipitation, BOT_PF, 16 and 17 July 2010

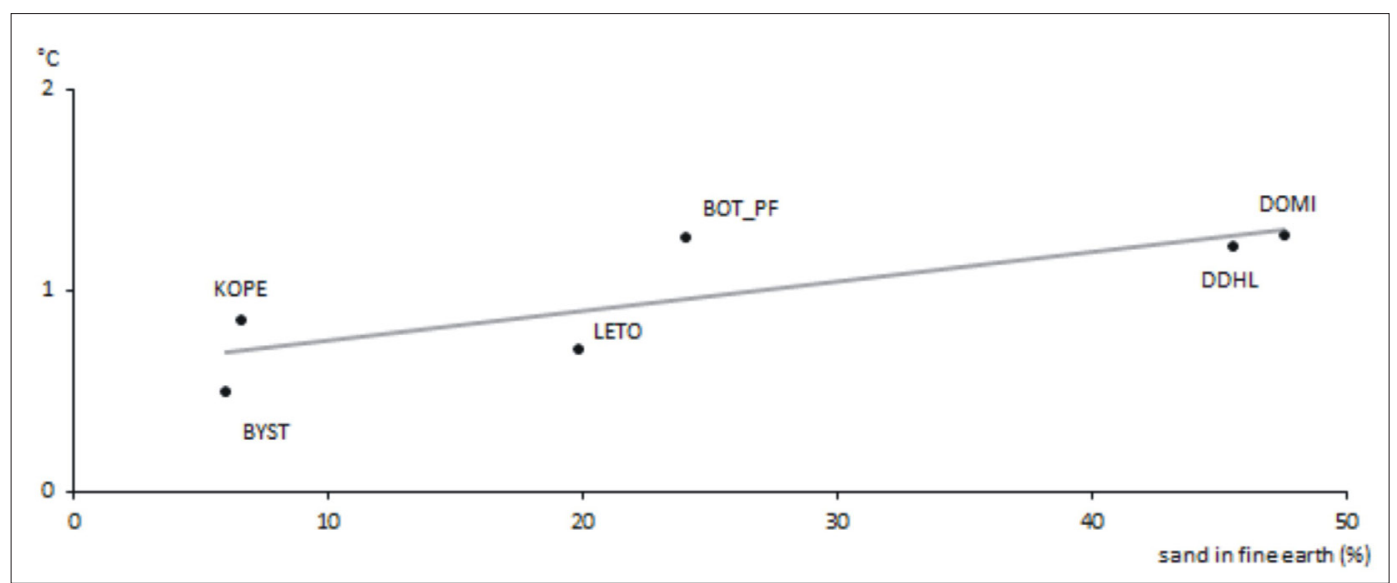

Fig. 8: Relation between the average diurnal soil temperature amplitude and the percentage of sand in fine earth, MESSO, 2010-2011 
identified as well as their interactions. At the same time, for further research it is necessary to verify the feasibility of the approach presented here for soil temperature simulation. Therefore, we experimentally used a variable to quantify local soil temperature specifics in the soil temperature simulation.

The basic version of the Zheng et al. (1993) model calculated for Olomouc and its surrounding areas showed satisfactory results (Fig. 9). Subsequently, an implicit LGF variable was included to quantify the local specifics (in the sense of the influence of possible geofactors on the soil temperature) at each station. Thus, $F(J)$ can be expressed as

$$
\begin{gathered}
F(J)=[A(J)-A(J-1)] M_{2}+E(J-1) \pm L G F \\
\text { where }
\end{gathered}
$$

$\left[+L G F\right.$ for $A(J)<A\left(J_{11 a v g}\right) ;-L G F$ for $\left.A(J)>A\left(J_{11 a v g}\right)\right]$

and $A\left(J_{\text {l1avg }}\right)$ is the running average counted for the previous 11 days. The LGF was based on a comparative analysis of soil temperature regime and air temperature regime. At this time, the LGF variable that was used and the method used to establish it are not of essential importance, since the introduced procedure represents only the innovated approach principle.

The model with the LGF variable showed slightly better results than the original model (Fig. 10, Tab. 4). Consequently, an adjusted version of the model based on the 2010 data series was calculated for the year 2011, with the result that the R2 value decreased by only 0.05 . To summarize, the model presented here might cover the spatial variability of soil temperatures with good results for Olomouc and its surrounding areas. Nevertheless, the LGF variable should be established empirically to obtain a better more applicable outcome of the research. However, the empirical determination of LGF requires long-lasting and more detailed measurements.

\section{Conclusion and discussion}

The analyses of MESSO soil temperature data series from 2010 and 2011 present essential information about the soil temperature regime in Olomouc and its surrounding areas. Based on analyses of the influence of meteorological factors, relief was identified as the most substantial geofactor determining the spatial variation of the soil temperature regime in Olomouc and the surrounding areas. The impact of relief on the soil temperature regime was associated primarily with atmospheric inversion, with the exception of the DDHL station where shading had an important role as well.

\begin{tabular}{|l|c|r|r|c|c|}
\hline \multicolumn{1}{|c|}{ Station } & A & B & C & D & E \\
\hline DDHL & 1.2 & 1.4 & -0.4 & 1.8 & 1.0 \\
\hline DOMI & 1.2 & 1.5 & -0.3 & 1.8 & 1.0 \\
\hline BOT_PF & 1.3 & -0.2 & -1.1 & 0.9 & 1.3 \\
\hline LETO & 1.4 & 0.9 & -1.1 & 2.0 & 1.0 \\
\hline KOPE & 1.6 & 1.5 & -1.0 & 2.5 & 1.2 \\
\hline BYST & 1.2 & 1.4 & -0.6 & 2.0 & 0.9 \\
\hline Avg & 1.3 & 1.1 & -0.8 & 1.8 & 1.1 \\
\hline
\end{tabular}

Tab. 4: Results of experimental average daily soil temperature simulation accuracy at MESSO: A) Average error for the original model; B) Average correction for days with increasing air temperature; $C$ ) Average correction for days with decreasing air temperature; D) Absolute value of correction; E) Average error for LGF compacted model

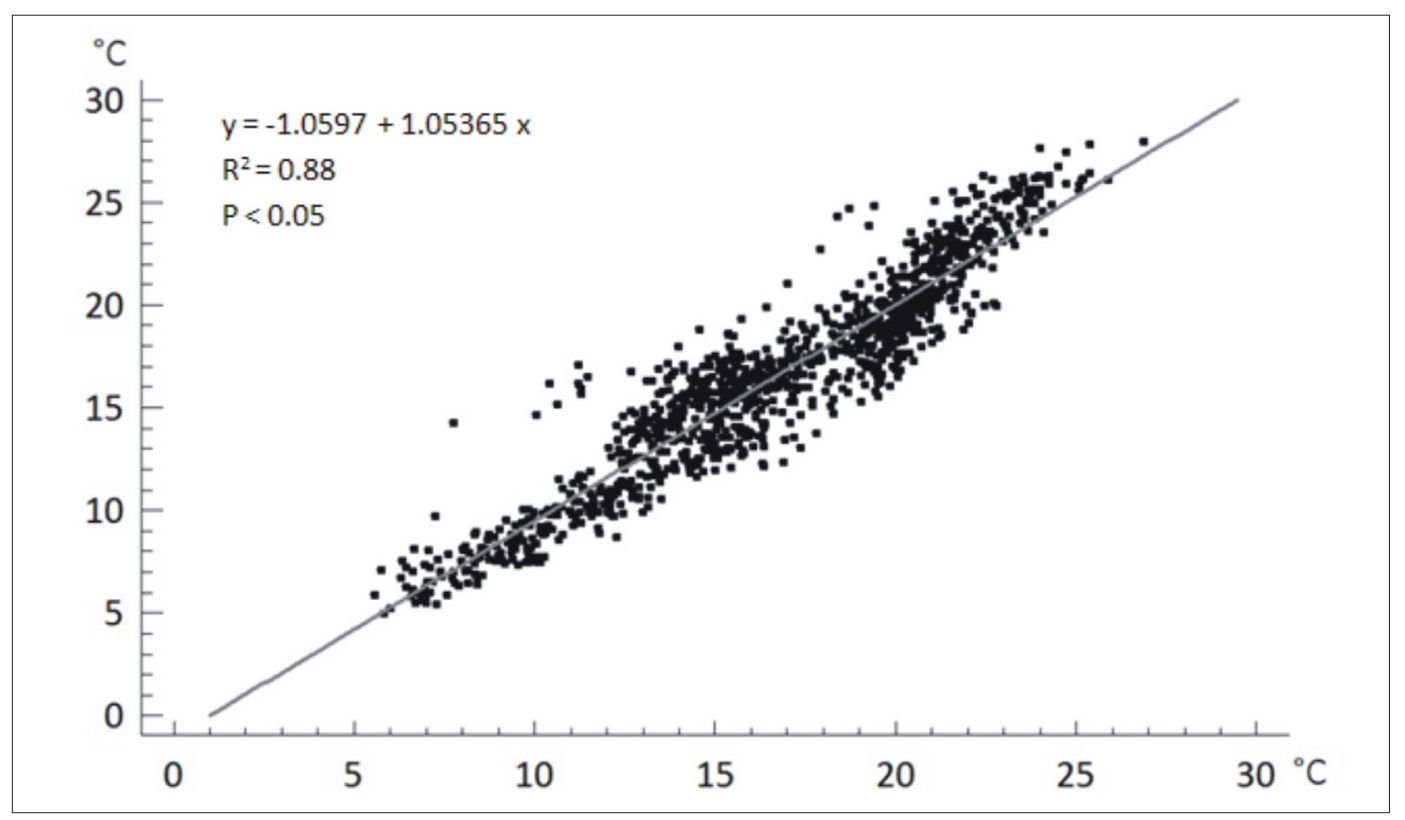

Fig. 9: Correlation between the measured and simulated average daily soil temperatures for the original model 


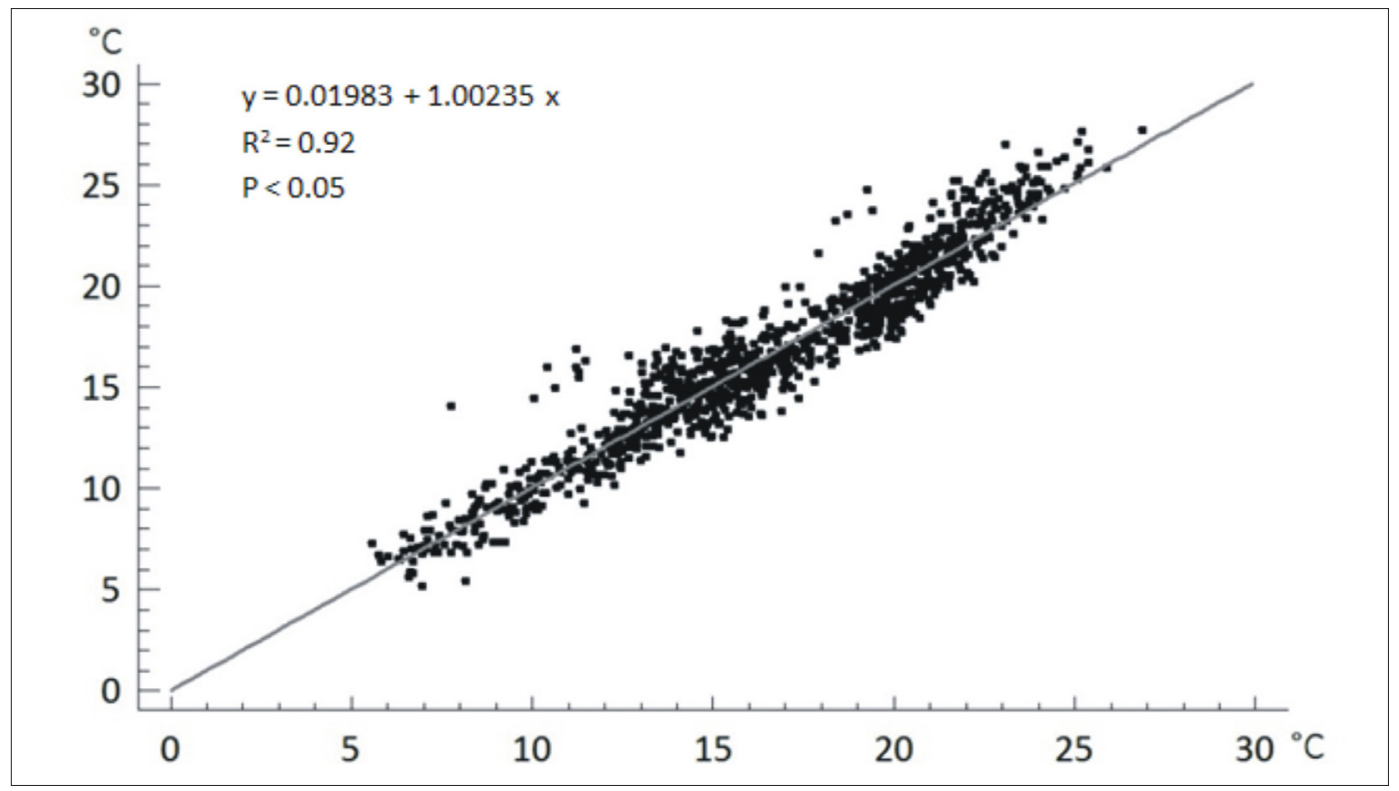

Fig. 10: Correlation between the measured and simulated average daily soil temperatures for the LGF modified model

Global radiation, as the most determinant factor influencing the soil temperature regime, was reduced by low cloudiness locally associated with air temperature inversion. Furthermore, the influence of the remaining cloudiness in terms of its spatial variation must be specified. Apart from the cloudiness itself, the instant impact of precipitation on soil temperature was confirmed. Therefore, the spatial and temporal variation of precipitation falling onto the Earth's surface may sharpen the spatial differences of soil temperature. Even a thin snow cover smoothed the soil temperature regime radically. For this reason, precise snow cover measurements should be made in further studies of soil temperature regime.

Since many authors have confirmed that soil properties have a significant influence on the soil temperature regime, the relation between the sand content in fine earth and daily soil temperature amplitude, as well as the relation between the soil humus content and daily soil temperature amplitude, were investigated. It was shown that there were no statistically significant relations between the values. Soils with a higher sand content in fine earth, however, seemed to have higher daily soil temperature amplitude. Moreover, the DDHL station with gleysol showed the second highest maximum temperature but also the lowest average annual temperatures. This is in agreement with Abu-Hamdeh et al. (2000) who found higher thermal conductivities in sandy soils than in clay loam soils. A further and more detailed analysis of physical and chemical soil properties would be useful to avoid confusion in the interpretation of the influences of local climate factors on the soil temperature regime.

The model developed by Zheng et al. (1993) can be considered a satisfactory tool for further attempts at interpretation and simulation of the spatial variability of soil temperature on a local scale. However, future attempts to interpret the variability of the soil temperature regime must be focused on a smaller area such as a pedotope. Then, the variability of the soil temperature regime at the regional level could be assessed, for example, by using methods of regional typology.

\section{Acknowledgement}

This research project was funded by the Czech Grant Agency, Project No. 205/09/1297: "Multilevel analysis of the urban and suburban climate taking medium-sized towns as an example”.

\section{References:}

ABU-HAMDEH, N. H., REEDER, R. C. (2000): Soil Thermal Conductivity: Effects of Density, Moisture, Salt Concentration and Organic Matter. Soil science society of America Journal, Vol. 64, No. 4, p. 1290-1296.

BALLAND, V., ARP, P. A. (2005): Modeling soil thermal conductivities over a wide range of conditions. Journal of Environmental Engineering and Science, Vol. 4, p. 549-558.

BEDRNA, Z., GAŠPAROVIČ, J. (1980): Typy teplotného režimu pôd ČSSR. Geografický časopis, Vol. 38, No. 1, p. 60-77.

COUFAL, V., KOTT, I., MOŽNÝ., M. (1993): Národní klimatický program ČR: Teplota půdy v chladné části roku v období 1961-1991 na území České republiky. Český hydrometeorologický ústav, Praha, 37 pp. 
DE VRIES, D. A. (1952): Het Wärmtegeleidingsvermogen van grond. In: Geiger, R., Aron, R. H., Todhunter, P.: The Climate Near the Ground. Rowman \& Littlefield publishers, Inc., Lanham, p. 142-144.

ELIZBARASHVILI, E. S. et al. (2007): Specific Features of Soil Temperature Regimes in Georgia. Eurasian Soil Science, Vol. 40, No. 7, p. 761-765.

GEIGER, R., ARON, R. H., TODHUNTER, P. (2003): The Climate Near the Ground. Rowman \& Littlefield publishers, Inc., Lanham, $584 \mathrm{pp}$.

GREEN, F. H. W., HARDING, R. J, OLIVER, H. R. (1984): The relationship of soil temperature to vegetation height. Journal of Climatology, Vol. 4, p. 229-240.

HANKS, R. J. (1992): Applied Soil Physics: Soil Water and Temperature Applications. Springer-Verlag, New York, 176 pp.

HOFMANN, G. (1955): Die Thermodynamik der Taubildung. In: Geiger, R., Aron, R. H., Todhunter, P. (2003): The Climate Near the Ground. Rowman \& Littlefield publishers, Inc., Lanham, p. 124.

HORA, P. (2011): Vztah teploty půdy a různých půdních druhů. In: Středová, H., Rožnovský, J., Litschmann, T. [eds.]: Mikroklima a mezoklima krajinných struktur a antropogenních prostředí. Skalní mlýn 2-4. 2. 2011.

HORTON, R. HOCHSTER T. (2012): Soil thermal properties. In: Huan, P. M., Li, Y. Sumner, M. E [eds.]: Handbook of soil sciences : properties and processes. $2^{\text {nd }}$ edition. Taylor \& Francis Group, Boca Raton, p. 9.1-9.23.

KANG, S., KIM, S., LEE, OH. D. (2000): Predicting spatial and temporal patterns of soil temperature based on topography, surface cover and air temperature. Forest Ecology and Management, Vol. 136, p. 173-184.

KUTÍLEK, M. (1990): Hypotermické režimy půd. In: Němeček, J., Smolíková, L., Kutílek, M.: Pedologie a paleo-pedologie. Academia, Praha, p. 86-99.

LEHNERT, M. (2010): Příspěvek ke studiu místního klimatu na území Př́rodního parku údolí Bystřice: Režim teploty půdy a vzduchu. Bakalářská práce. Univerzita Palackého v Olomouci, Olomouc, 85 pp.

LEHNERT, M. (2012): Režim teploty půdy v městské a příměstské krajině (Olomouc a okolí). Diplomová práce. Univerzita Palackého v Olomouci, Olomouc, 104 pp.

NOSEK, M. (1972): Metody v klimatologii. Academia, Praha, 434 pp.

OKE, T. R., HANNELL, F. G. (1966): Variation of temperatures within a soil. Weather, Vol. 21, p. 21-28.

POKLADNÍKOVÁ, H., ROŽNOVSKÝ, J., DUFKOVÁ, J. (2006): Promrzání půdy na stanicích Pohořelice, Vizovice a Bystřice nad Pernštejnem. Meteorologické zprávy, Vol. 59, No. 5, p. 135-140.

TESAŘ, M., ŠÍR, M., KREJČA, M., VÁCHA, J. (2008): Influence of vegetation cover on air and soil temperatures in the Šumava Mts. (Czech Republic). [on line]. IOP Conference Series: Earth and Environmental [cit. 6. 1. 2013]. Available at URL: http://iopscience.iop.org/1755-1315/4/1/012029/.

TOLASZ, R. et al. (2007): Atlas podnebí Česka. ČHMÚ v koedici s Univerzitou Palackého v Olomouci, Praha, Olomouc, 255 pp.

VYSOUDIL, M. et al. (2012): Podnebí Olomouce. Univerzita Palackého v Olomouci, Olomouc, 212 pp.

VYSOUDIL, M. (2008): Surface Atmosphere Layer Temperature Regime (Case Study of the Nature Park Bystřice River Valley, The Nízký Jeseník Highland, Czech Republic). Moravian Geographical Reports, Vol. 16, No. 3, p. 41-56.

VYSOUDIL, M. (2009): Klasifikace místních klimatických efektů. Geografický časopis, Vol. 61, No. 3, p. $229-241$.

ZBÍRAL, J., HONSA, I., MALÝ, S. (1997): Analýza půd III : jednotné pracovní postupy. ÚKZUZ, Brno, 150 pp.

ZHENG. D., HUNT, R. E., RUNNING, S. W. (1993): A daily soil temperature model based on air temperature and precipitation for continental applications. Climate Research, Vol. 2, p. 183-191.

\section{Author's address:}

Mgr. Michal LEHNERT

Department of Geography, Faculty of Science, Palacký University Olomouc

17. listopadu 12, 77146 Olomouc, Czech Republic

e-mail: michal.lehnert@gmail.com

Initial submission 26 March 2013, final acceptance 14 June 2013

Please cite this article as:

LEHNERT, M. (2013): The soil temperature regime in the urban and suburban landscapes of Olomouc, Czech Republic. Moravian Geographical Reports, Vol. 21, No. 3, p. 27-36. DOI: 10.2478/mgr-2013-0014. 